\title{
口蓋裂術後残遺孔に対する閉鎖床の一試案
}

\author{
福田登美子・西村 敏 治*・溝川信子
}

後藤友信・和田健・宮崎正

\section{A new type obturator for the post-operative fistula of cleft palate cases}

\author{
Tomiko Fukuda - Toshiharu Nishimura* - Nobuko Mizokawa
}

Tomonobu Goto - Takeshi WadA - Tadashi Mryazaki

はじめに

口蓋裂形成手術後にみられる残遗孔は，口蓋裂手術の 方法，手技により出現率は異なると思われるが，特に術 後の鼻咽腔閉鎖機能を重視した push back operationで はとの出現率は高いと考兄られるい

残遗孔の存在が口腔諸機能に及ぼす障害はその存在す る位置，大きさにむよるが，直接的には食物残糟の孔内 停留, 鼻孔への洩出拉よび言語面にもみられ，患者およ び両親の心理障害を花起する。したがって，その適切な 処置は術後炕和ける重要な課題である.

処置方法としては手術と閉鎖床がある。手術の場合 は，有茎弁移植や再度の口蓋粘膜弁による閉鎖方法が考 光られるが，これを低年龄児に行ら場合には罰発育の問 題，さらに言語治療の刘果などを総合して判定しなけれ ばならず多くの問題を含む。その点閉鎖床は簡単に作製 でき，取りはずしも可能であり，また，残遗孔を塞ぐこ とにより，それがどの程度有効であるかという判定にも 役立つ。しかし，従来の閉鎖床は写真1のような鈎を楼 牙にかける休式である。これは鈎歯に維持を頼るため に，鈎菌の条件が要い場合は装着が困難であり，必要な 時期涜着できずに放置せざるを得ないことも多い．す なかち, 維持雨が未萌出の場合や冠豊隆が少ない場 合，またう歯や残根状態のもの，さらに矯正治療中のる のは装着不能となる。

一方，装着可能な場合でる䫇発育を抑制する，鈎県の

大阪大学齿学部附属病院枵口腔機能治療部（主任： 宮崎 正教授)

*大阪厚生年金病院菌科

Division of Functional Therapeutics for Stomatognathics, Osaka University Dental School Hospital (Chief: Prof. Tadashi Miyazaki)

* Osaka Kosei-Nenkin Hospital, Depart. of Dentistry

受付日：昭和53年11月13日

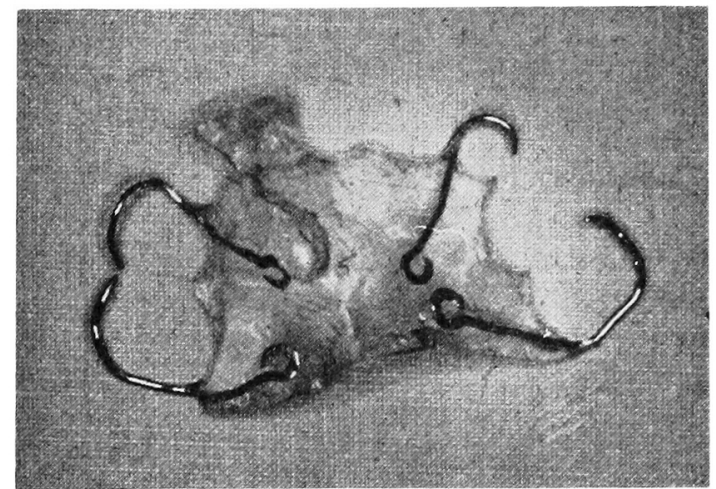

写真 1 鈎を有する閉鎖床

5蝕を誘発促進させる，鈎潾近接部位に歯肉炎を誘発さ せるなどの問題が生じやすい，加えて鈎作製上の手間る かかる.

こういった臨术上の悩みから，われわれは鈎を使用せ ずによ゙のよらな症例にも装着でき，かつ簡単に作製でき る閉鎖床を考案し積極的に装着し効果を得ているので報 告する.

\section{研 究 方 法}

1) 対象

対象は阪大曾学部口腔外科および他院で口蓋裂形成術 を受け，奤口腔機能治療部で言語治療中の患罗21例であ る。

21例の装着前の状態は表 1 火示す。装着時年柃は 2 歳 4 か月から 7 歳 8 かににわたり， 5 歳以上が 6 例， 4 歳

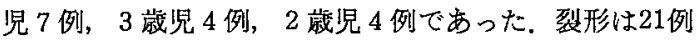
中15例が両側性口唇口蓋裂，6例が片側性口唇口蓋裂で あった．残遺孔の部位は，過半数のものが歯槽部から硬 口蓋にかけて形成され，6 例は鋤骨を中心に孔が 2 分さ れていた，大きさは小豆大から大豆大であった，21例炕 
表 121 例の装着前の状態

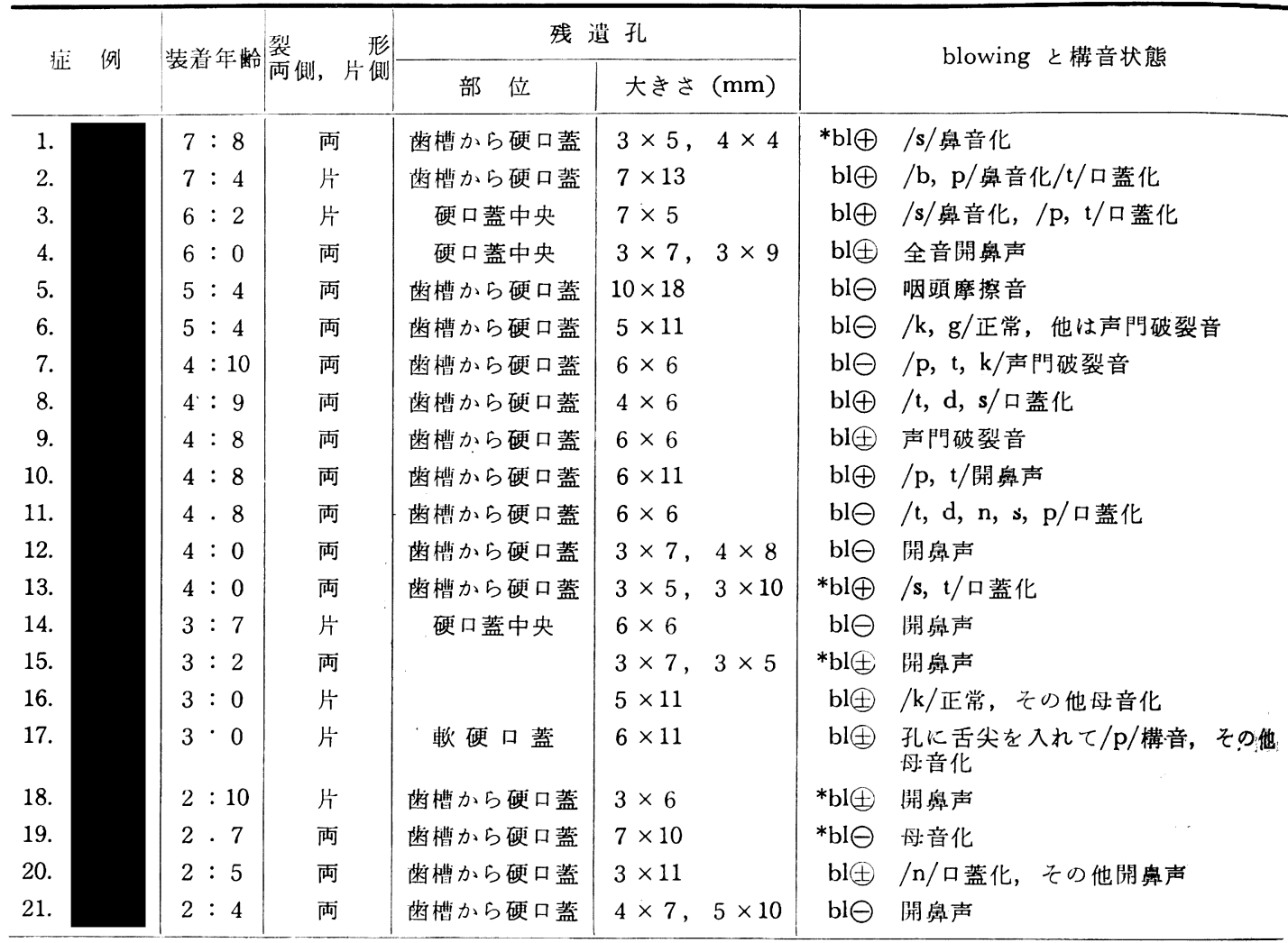

过 $\mathrm{bl} \oplus:$ 吹き戻しが吹き続けられるもの, $\mathrm{bl} \oplus ：$ 一過性に延長できるもの， $\mathrm{bl} \ominus: \mathrm{bl} \oplus$ 以下，*：構音以外に も問題を有するもの

は言語発達, 聴力, 情緒面に特記すべき問題はなかっ た。装着前の構音状態は, 開番声および一部の音に舅音 化を示したもの 8 例, 開鼻声と口蓋化音 3 例, 口蓋化音 の又 3 例, 声門破裂音 3 例, 母音化 3 例, 咽頭摩摖音 1 例であった，吹き出し状態は，吹き戻しが吹き続けられ るもの 6 例, 一過性に吹けたもの 7 例, それ以下のもの 8 例であった。

\section{2）装着例判定方法}

閉鎖床の適応例判定には，弾性義嵝安定材を孔に暫间 的に㨀入し，挿入前後の構音や吹き出乙能の変化，およ び鼠腔漏出父量测定結果から決定した。

啃音の判定は，防音室にて録音した恶韭の音声を再生 聴取し，開鼻声や買常楧音状態の変化を調べた， $2 \sim 3$ 緺児には絵本をみせて発語させ，4藏以上では絵カード をみせて単語を自発的にいわせた。録音は口崀より約 20 $\mathrm{cm}$ 離したマイクロフォン（ソニー製 ECM-56A) を通 し, 最大入力音声レベルが $0 \mathrm{~dB}$ を越えないようにテー フレコーダー（ソニー製 TC 707 SD-R）を調整して 行った.
吹き出し能の測定には，吹き戻しを使用した，吹き戻 しが吹き続けられる場合を $\oplus$ とし，一過性に延長でき る場合をÐ，それ以下の場合を $\ominus$ として評価した。

畺腔漏出気量の測定は，多用途監視装固を用いて薁腟 と口腔からの呼気流出量比を調べた。 しかし，2３歳 児では㭘査が困難な場合が多く，可能な患罗にのみ行っ た。

以上の結果から閉鎖床が有効であると判定した症例に 装着した。

\section{3）閉鎖床の作製方法}

今回われわれの考案した閉鎖休は，鈎を使用せずに残 遺孔のアンダーカットを利用して維持するものである. レジンまたはセルロイドで基礎床を作製し，その上に弾 性印象材または過装材を盛りあげて残遺孔部分を閉鎖し ている.

すなわち

1) 残遗孔を含めた上䫈の印象採得（アルギン酸系 またはシリコン系の印象材).

2 ）石缡模型作製（第 1 次模型之第 2 次模型）１ 


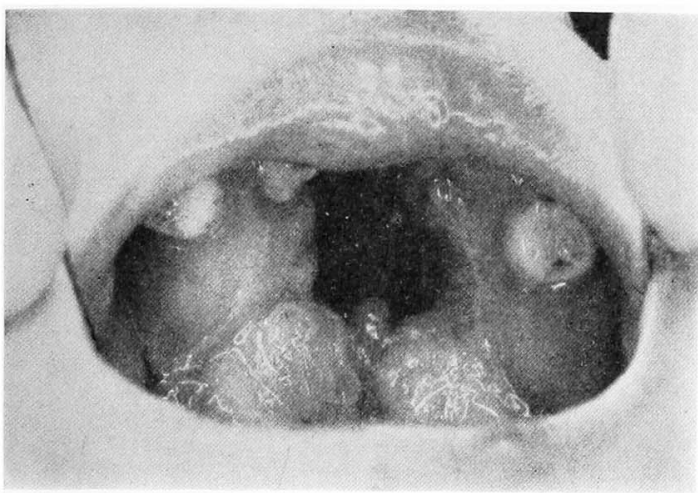

写真 2 症例 13 , 装着前

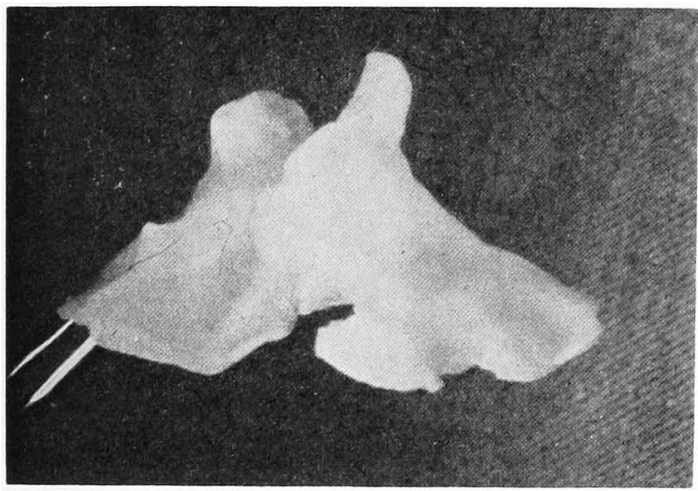

写真 3 症例13の閉鎖床

次模型の残遺孔部をワックスで仮封成形したものを再 印象した 2 次模型を作製する。

3）基礎床の作製

この 2 次模型上でレジンまたはセルロイド製の薄い 口蓋床を作製し基礎床とする。床の外形線は写真 4 亿 みられるように全硬口盍を和打ら型と，写真 6,8 の よらにいわゆる栓塞子型のものがあり，これは残遺孔 の形態 (特に入口の形状とアンダーカットの形態), 患者の年齡などを考慮して決定している，硬口蓋を広 く㧍括ら型はほとんどの症例に適応できるが，孔のみ を沶う型は，孔の入口周辺の凹みが著明で，小さい 林のみです口蓋が滑らかに形造られるよらな症例で, 年龄的にも誤领しない 4 歳以上位に適用される。写真 8 の栓塞子型では基礎床に相当する部分も栓塞子と同 材のむので一塊物として作製した。

4) 維持部の作製

直接法は, 基礎㕅の粘膜側に弾性裏装材を盛りあ げ，㭧児の口腔内にて硬化をはかる方法である．硬化 後は，いったん取り出して 余剩部分の削除研磨を行 5 .

間接法は 1 次模型上で同様の作業を行らが，これは

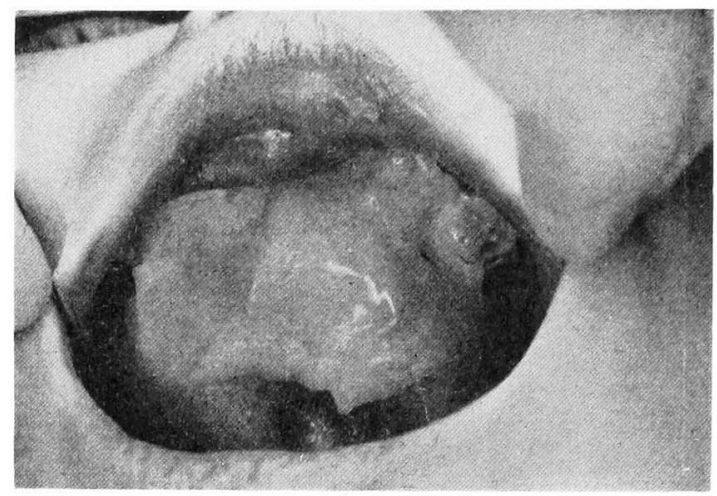

写真 4 症例 13 , 装着後

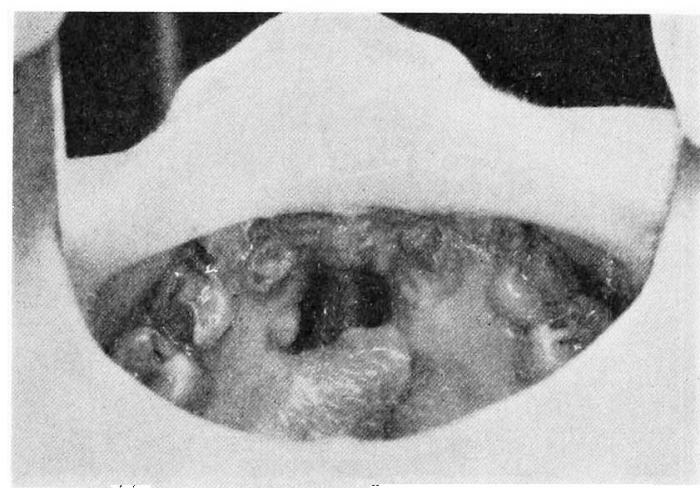

写真 5 症例15の装着前

低年齢児や残遺孔の中心に鐁骨が存在し孔が 2 分され ている場合，残遺孔のアンダーカットの大きい場合な どに適している，栓塞子型はもっぱら模型上で作製す る. いずれも作製は短時間しか要せず遠来の急者はそ の日に装着して帰宅できる。

4) 蒋着実例

写真 2〜 4は症例13に装着したものである. 本症は構 音と摄食時に障害がみられた。閉鎖床は硬口蓋を広くお おう型を装着した。

写真 5, 6 は症例 15 装着したものである. 小さいセ ルロイドの基礎床に弾性印象材 visco-gel を盛りあげ鐁 骨のフンダーカットに維持を求めたいわゆる栓塞子型で ある.

写真 7.8 は症例17に装着したもので，ほとんどの歯 牙が残根状態である，床縁の違和感を防ぐために残遗孔 入口周辺の凹みに限局した栓塞子型を用いた。

写真 $9 \sim 11$ 症例 5 に装着したものである. 矯正医に よって上顎函列弓の側方拡大が積極的に行われた結果， 裂隚様の牫遣孔が非常に拡大されたものである。鈎式の 閉鎖床であれば矯正装置が装着されている期間中は閉鎖 㦿は困難であるが，本法のよ5に基礎床に裂隙のアンダ 


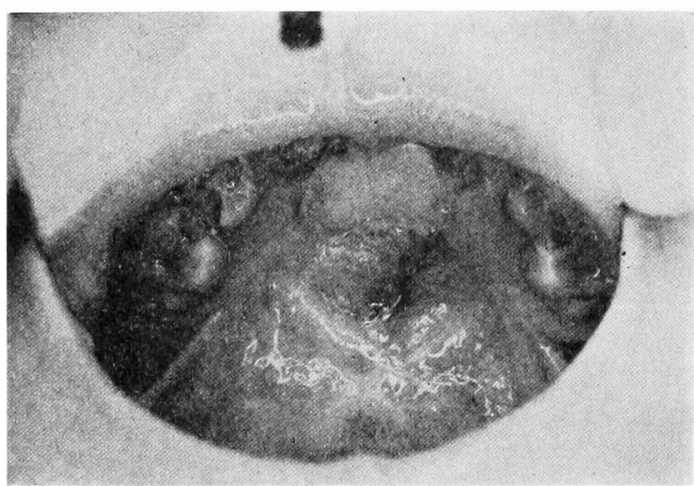

写真 6 症例 15 装着後（栓塞子型）

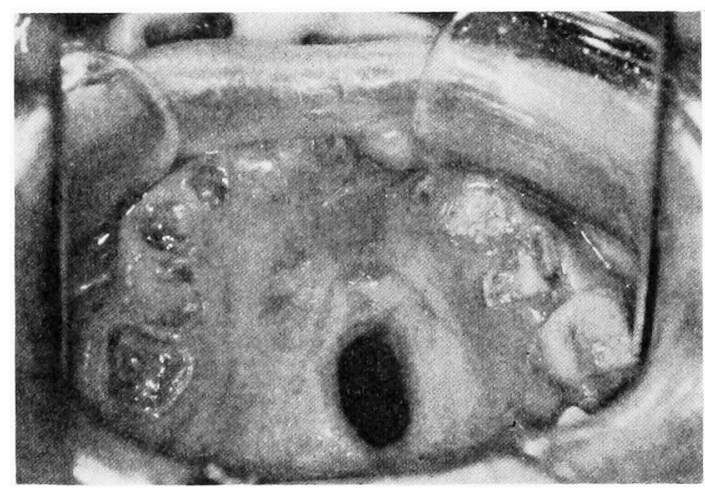

写真 7 症例17の装着前

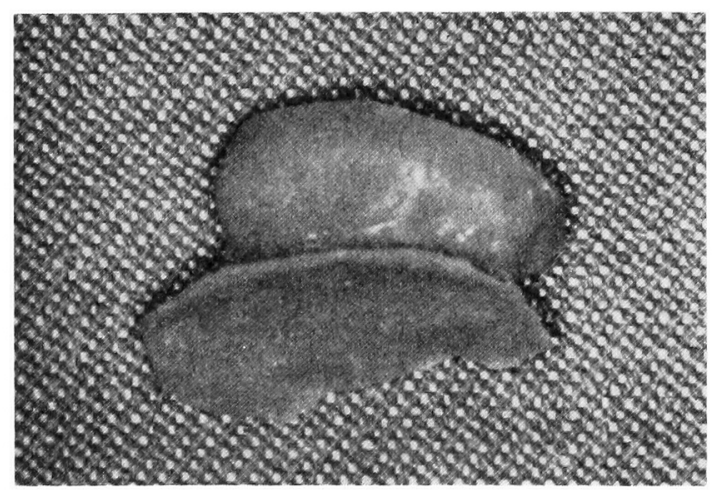

写真 8 症例 17 栓塞子

ーカットへの栓塞維持を求めたるのであれば，基礎㕅の 大きさを加減すれば短正装固との併用む可能である.

\section{装着 6 か月後の結果}

\section{1）吹き出し能について}

装着後の吹き出しの状態は表 2 に示すとおりである.

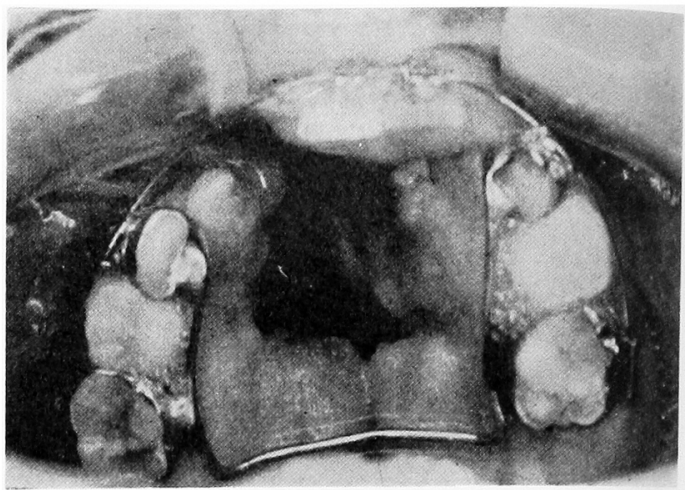

写真 9 症例 5 の装着前

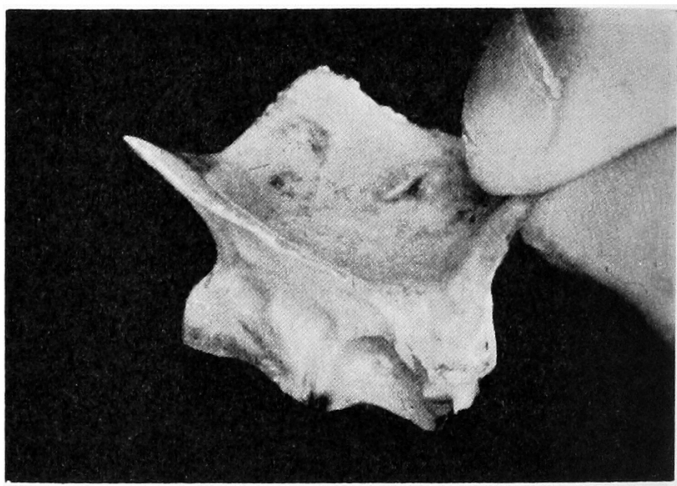

写真 10 症例 5 の閉鎖床

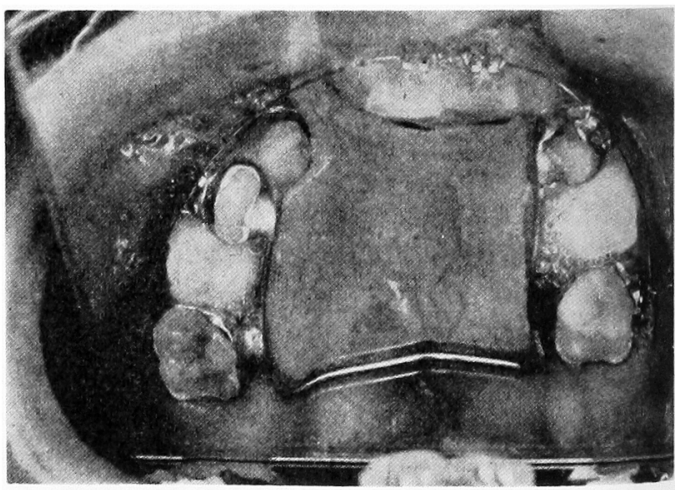

写真 11 症例 5 の装着後

判定は装着前の判定と同㥞の方法を用いた。 装着後吹き出し能が円となったるのは17例，丹が4 例となり，装着前には全く吹けなかったものも含めて全 貣が改善した。全員に対し閉鎖休装着後口唇をとして界 腔で吹かせたり，運動をさせたが脱落したものは 1 例る なかった。

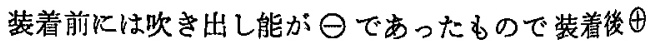


になった症例 $6 ， 7 ， 11 ， 21$ の 4 例について孔の大きさ をみると， $5 \times 11 \mathrm{~mm} 1$ 例， $6 \times 6 \mathrm{~mm} 2$ 例， $4 \times 7$ $\mathrm{mm}$ と $5 \times 10 \mathrm{~mm}$ の 2 個を有する 1 例であった。 また， 吹き出し能が円にとどまった症例 $5 ， 12 ， 14 ， 19$ の 4 例の孔の大きさは, $10 \times 18 \mathrm{~mm} 1$ 例, $3 \times 7 \mathrm{~mm}$ と 4 $\times 8 \mathrm{~mm} 1$ 例, $6 \times 6 \mathrm{~mm} 1$ 例, $7 \times 10 \mathrm{~mm} 1$ 例で雨 群の孔の大きさには著明な差はなかった。

また，装着前から吹き出し能 $\oplus$ のものの孔の大きさ と, 装着後 $\oplus$ にったものの孔を比較すると，装着前 から円であった群の中に，装着後 $\oplus$ にったものより 大きい孔存在した。

孔の部位に関してはいずれの群も類似していた。

\section{2）構音について}

装着後の構音状態は表 3 に示すとおりである。判定は 装着前検査と同じ方法を用いて行った，構音が改善した と判定したものは17例である。このうち著明に改善した ものは10例でこれは正常構音となったものである。 7 例 は単語レベルでは改善したものの会話時に翼常構音およ

表 221 例の装着前後の Blowing

\begin{tabular}{|c|c|c|c|}
\hline Blowing の状態 & 年 龄 群 & 装 着 前 & 装着後 \\
\hline \multirow{4}{*}{ 十分吹ける(閉鎖円) } & 5 歳以上 & 3 例 & 5 例 \\
\hline & 4 歳 & 3 & 6 \\
\hline & 3 歳 & 0 & 3 \\
\hline & 2 歳 & 0 & 3 \\
\hline \multirow{4}{*}{ はぼ吹ける（甲） } & 5 歳以上 & 1 & 1 \\
\hline & 4 歳 & 1 & 1 \\
\hline & 3 歳 & 3 & 1 \\
\hline & 2 歳 & 2 & 1 \\
\hline \multirow{4}{*}{ 吹けない（Ө) } & 5 歳以上 & 2 & 0 \\
\hline & 4 歳 & 3 & 0 \\
\hline & 3 歳 & 1 & 0 \\
\hline & 2 歳 & 2 & 0 \\
\hline
\end{tabular}

び開鼻声が残存した。 また，舌尖を孔へ挿入する習慣は 1 か月以内に消失した。

今回装着した21例中 4 例には改善がみられなかった。 寸なわち 1 例は閉鎖床を装着しても変化がなかったもの である。この症例12は装着前に胃咽腔閉鎖機能にも問題 があると判定したが， speech aid は嘔吖反射が強く中 止せざるを得ず，次善の策として閉鎖床を装着したので あるが，6か月後吹き出し能が甲になったのみで構音 には変化はなかった。

他の 3 例は一部の棈音は改善したにもかかわらず新た な障害音が出現した。症例 6 は装着後 1 か月で吹き出し および破裂音は改善したが 3 か月後に/s/音が口蓋化音 を示した。症例 9 は吹き出しおよび無声破裂音は改善し たが/n/音が口蓋化音を示した. 症例 2 は 1 か月後に/p/ 音が改善したが， 4 か月後に/n，t， d, p/音が口葢化音 を示した. 3 例ともに判定時には改善していない.

\section{3）その他の問題について}

今回閉鎖床を装着した 21 例の5ち，装着前に構音以外 に孔に起因する問題を訴えていた症例が 5 例あった。捕: 例 1 は食屑の王入と孔からの悪臭を訴え, その他13，15, 18，19の 4 例も食事中または食後に不快感を訴え，母親 は食屑の除去に悩まされていた。閉鎖床装着後は食屑の 圧入，液体の勫腔漏出，悪臭などの問題はただちに解消 し，床を装着して食事をしても脱落もなく患児らはすす んで装着を希望している，一方母親は食事中の悩みの解 消に加え，人前で鼻腔から液体が流出する不安や，残遺 孔が人にみえるのではないかといら不安も解消し心理的 効果も認められた。

\section{考察}

口蓋裂形成術後にみられる残遺孔の手術的閉鎖法には 口蓋粘膜組織による有茥弁移植 ${ }^{5,6)}$ や舌弁移植 ${ }^{7,8)}$, 中間 層皮璒移植などが報告されてきた。このような手術によ る閉鎖は最終的処置法としては有効であるが，一方，手 術に伴ら患者や家族の負担，また顎発育への影響などを

表 32 21例における装着前後の構音状態

\begin{tabular}{|c|c|c|c|c|c|}
\hline \multirow{2}{*}{ 装 着 前 } & \multirow{2}{*}{ 例 数 } & \multicolumn{2}{|r|}{ 装 } & \multicolumn{2}{|l|}{ 後 } \\
\hline & & 著明に改善した & 改善した & 変化なし & 新たな障害が出現 \\
\hline 開鼻声 • 鼻音化 & 8 & 2 & 5 & 1 & \\
\hline 開奥声十口蓋化音 & 3 & 2 & & & 1 \\
\hline 口蓋化 音 & 3 & 2 & 1 & & \\
\hline 声門破裂音 & 3 & 1 & & & 2 \\
\hline 母 音 化 & 3 & 3 & & & \\
\hline 咽頭摩擦音 & 1 & & 1 & & \\
\hline 計 & 21 例 & 10 & 7 & 1 & 3 \\
\hline
\end{tabular}


考虛すれば，いつどのような症例にも簡単に行える処置 方法とはいいがたい.

閉鎖床は暫定的処置であるが，着脱が自由であり，さ らに孔を閉鎖することがどの程度有効であるかといら判 定もできるという利点を有している。

さらに，今回の鈎無しタイプの閉鎖床は幽牙状態に関 係なく装着できる利点がある。唇顎口蓋裂児の口䅝環境 は, 同年の一般保育園児に比べきわめて悪く早期にう蝕 に罹患し，特に上顎前蒾や上下顎臼幽のら蝕が著しいこ とはすでに報告されている10)。このよらな好ましからぬ 口腔内に鈎つき閉鎖床を装着することは困難な場合が多 い.仮に装着できたとしても鈎歯のら蝕を促進させ口腔 環境を一層悪化させる原因となる.

これに対し鈎無し閉鎖床は口腔条件や対象児の年齢の 点からも適応䉐囲はきわめて広く, 装着後の清梁な口腔 環境維持の面からも問題は少ない。 また, 効果の上から もその有効性が示された。

作製上の問題点としては，技術的には印象時に孔の形 態によって印象材の選択や練和方法を工夫しなければな らないことである。アンダーカットが強く印象材が孔内 に入り切断された場合, 印象材を確夹に取り出すのは容 易でなく最も注意を要する点である.

基礎床の大きさは，孔よりひと周り大きくする程度で よいが，低年齡児では大き目に作製し誤飲の危険をさけ なければならない。

装着中の問題点としては，自分で着脱のできる郘児で は口腔内で弄んだり, 着脱時の取り扱いが乱暴なために 軟性樹脂や襄装材で作った插入部分が破損する扣それが ある. 現在当院では対象を徐々に低下し $2 \sim 3$ 藏児を主 体に装着しているが, 補経物の装着を 2 〜 藏児に行 場合は何よりも患児との rapport が重要で，無理に装 着した場合は恐怖心を与えるのみである。特に 2 歳児で は母親と担当者が一体となって当たらなければ装着不能 となる。また，この年㱓では閉鎖床の着脱は母親が行わ なければならないため，母親の衛生観念や協力が効果を 左右するといえる.

次に閉鎖床の効果について考察を加えると，装着前吹 き出しが不能であった 8 例のうち 4 例は装着後閉鎖は $\oplus$ の状態になった。これは本来鼻咽腔閉鎖機能を有しつつ 孔の影響で吹き出し感覚が得られなかったものが，㠘腔 内にまで插入されている閉鎖床維持部分によって臿腔抵 抗が兽まり，吹き出し時の閉鎖感覚を獲得したものと考 えられる。ほかの 4 例が甲の状態にとどまたことは， これらの症例の有する問題が単に孔のみに存任するので はなく，鼻咽腔閉鎖機能自体に起因寸ると考えられる. しかし，吹き出しや構音へ及ぼす孔の影犁を判定すると き，単に孔の大きさや部位のみから決定することは困難 である．今回の結果でも類似した部位に存在する $6 \times 6$ $\mathrm{mm}$ の孔でも炜鎖効果の有るものとないものが存在す
ることから，閉鎖床装着例の判定は術後一定期間の訓練 の結果，孔の影響が疑われる場合には可及的早期に閉鎖 床を装着することが重要である.

残遺孔の構音への影響については，すでにいくつかの 報告がある．小さい孔は影響なし ${ }^{11)}$ との報告もあるが， 影響を認めたものが多い2〜4).

われわれの調査結果でも, 残遗孔は呼気の鼻腔漏出や 舌尖を孔へ插入する悪習慣，また，共鳴障害などの原因 となることがわかった. 木村2)は $6 \times 4 \mathrm{~mm}$ の孔が開奥 声の原因となったと郝告しているが，これは十分考兄ら れることである。

閉鎖床を装着したあと，効果出現までの期間は年齢に より差があった，床装着の目的が食屑や鼻臭の除去にあ る場合は，年踚に関わりなく短期間に効果がみられた が，構音を目的とした場合は 5 藏児では 6 か月， $3 \sim 4$ 歳児では $1 〜 4$ か月， 2 藏児では10日〜 3 か月であり， この結果からも低年龄で孔の影響を判定し処㯰する必要 性が示された。

孔に栓塞子を插入する閉鎖床が，破裂音や摩擦音の番 音化や口蓋化音の除去に有効であった点については, 補 綴物の装着により口蓋部の滑沢な移行形態への改善によ り，それが舌尖の効果的運畊機能を誘発したものと考兄 られる。一方, 通鼻音 $/ \mathrm{n} /$ や摩擦音/s/が口蓋化を示した ことは，本床が単に孔の入口を封ずるに止まらず，鼻腔 内にまで入り込ませているために通番音の構音を困難に し，これが摩擦音やその他の音に影響したものと考えら れる。アンダーカットが強い例では基礎床部分のみを装 着させ異常構音をきたさないような注意が必要である。

本床は構音以外に食屑の圧入を防ぐのに效果のあるこ とはすでに述べたが，親の心理面にも效果があることが わかった．残遺孔が親の心理に及ぼす影響については左 藤ら4) も指摘するとおりで，われわれもしばしば痛感し ているが，子どもが人前で笑ったり，口を開くたびに孔 が人にみられることを恐れている母親は多い. 阪大式閉 鎖床は，基礎床が薄く口蓋に密着しているため一見装着 していることが見分けられず，鈎つき閉鎖床より母親の 心理安定に有効であった。

\section{まと め}

口蓋裂形成手術後にみられる残遗孔に対する処置法の 1 つに閉鎖床がある。

阪大歯学部附属病院颛口腔機能治療部では, 閉鎖床の 一考案として残根状態でも装着できる鈎無しタイプのも のを考案し装着した結果, 郜床上効果を認めた.

この閉鎖床の特徵は,

(1) 将牙状態に関係なく装着できる.

（2）鈎を使用しないため審美的にも不自然でない.

(3)幅広い残遗孔でも十分維持可能である. 
(4) 口蓋に密着しているので違和感がない.

(5) 作製方法が簡単かつ短時間ですむ.

(6) 鼻腔側に 捜入されているため吹き出し感覚が得や すい.

(7) 保持装固を崡牙にもとめないため顎発育やら蝕に も影響を及ぼさない。

本論文の要旨は第24回日本口腔外科学会中国四国兵庫 地方部会（昭和51年11月広島）において発表した。

\section{引用文 献}

1) Fára, M.: Primary Pharyngofixation in Cleft Palate Repair, Plast. \& Reconst. Surgery 45: 4491970.

2) 木村 炤, 他：口蓋裂手術後の瘦孔について。 聴覚言語障害 3: 1451972.

3) Van Demark, D.R.: Assessment of articulation for children with cleft palate. C P J 11: 2001974.
4）佐藤美子, 他：嫩孔のスピーチに及ぼす影響. 聴覚言語障害 6: 471977 .

5) William C. Grabb, Sheldon W. Rosenstein, Kenneth R. Bzoch: Cleft Lip and Palate I. ed, Brown Co, Boston 1971, p. 490.

6) John Marquis Converse: Reconstructive Plastic Surgery 2.ed 4, W.B. Saunders Co, Philadelphia, London, Toronto, 1977, p. 2198.

7) Jose Guerrero-Santos, Jose Maria Fernandez: Further Experience with Tongue Flap in Cleft Palate Repair. Cleft Palate J 10: 192 1973.

8）高憍庄二郎, 他：舌弁使用による口蓋裂患者の 口蓋瘦閉鎖法について。 日口外誌 19:601 1974.

9）河合 幹，他：中間層皮虞移植に上る口蓋前方 瘦の一手術的閉鎖法。日口外誌 22：1201976.

10）神山紀久男, 他：口蓋裂患者の5蝕羅患に関す る実態調查。日口蓋誌 2：30 1977.

11) H. Westlake, D. Rutherford 著。中田幸代, 吉沢典男訳：口蓋裂。第 2 版, 日本交化科学社, 東京, 1970, 110頁. 